\title{
Spread of cymbidium mosaic potexvirus and potyviruses in vanilla plants grown in shade houses in Reunion Island
}

Françoise Leclercq-Le Quillec*, Claude Rivière, Anne Lagorce

Cirad-Flhor,

BP 180 ,

97455 Saint-Pierre,

Île de la Réunion

leclercq@cirad.fr
* Correspondence and reprints

Received 5 October 2000 Accepted 4 April 2001

Fruits, 2001, vol. 56, p. 249-260 (C) $2001 \mathrm{Cirad} /$ EDP Sciences All rights reserved

RESUMEN EsPañol, p. 259

\section{Spread of cymbidium mosaic potexvirus and potyviruses in vanilla plants grown in shade houses in Reunion Island.}

Abstract - Introduction. Beginning in 1994, vanilla vines grown under shade houses in Reunion Island have developed disorders mainly due to the cymbidium mosaic potexvirus (CymV) and potyviruses. To reduce damage and avoid viral epidemics, we considered developing a vanilla nursery to supply farmers with virus-free plant material and to provide prophylactic advice. Accordingly, we determined the relationship between symptoms on vanilla leaves and viral diagnosis. We also determined the temporal and spatial distribution patterns of viral diseases. Materials and methods. Symptom assessment and serological tests were carried out on vanilla leaves (Vanilla fragrans) at various times. The relationship between symptoms and viral infection data was analyzed with Statistica software. Spatial distribution patterns of infected plants were generated with two-dimensional distance class analysis (2DClass). Results and discussion. Results showed that symptoms do not correlate well with serological diagnosis. Plants in all shade houses in the survey were infected mainly by CymV which spreads in the row according to cultural practices. Potyviruses could be transmitted both by insect vectors and mechanically, but for the latter case less efficiently than CymV. Conclusion. Results from this study can be used to develop control measures, including the production of healthy planting materials to manage plant disease epidemics. Further studies will involve the characterization of vanilla potyviruses so that reliable serological techniques and better molecular tools can be developed.

Reunion / Vanilla fragrans / disease surveys / protected cultivation / potexviruses / potyviruses / symptoms / disease transmission / epidemiology

\section{Dissémination sous ombrière du cymbidium mosaic potexvirus} et de potyvirus affectant les lianes de vanilliers cultivés à l'île de la Réunion.

Résumé - Introduction. Depuis 1994, le dépérissement du vanillier, cultivé en système intensif sous ombrière à l'île de la Réunion, est principalement dû au "cymbidium mosaic virus » (CymV) et aux potyvirus. Pour limiter les dégâts et mieux contrôler l'épidémie virale, nous avons étudié la relation entre la présence de symptômes et le diagnostic viral ainsi que la dynamique temporelle et spatiale des virus sous ombrière. Ces études ont été utilisées pour apporter de judicieux conseils prophylactiques et mettre en place une pépinière de boutures de vanillier afin de fournir aux planteurs du matériel végétal indemne de virus. Matériel et méthodes. L'observation des symptômes et le diagnostic sérologique ont été réalisés à partir de feuilles de vanille (Vanilla fragrans) à l'occasion de différentes prospections sous ombrières. La relation entre l'expression des symptômes et les données d'infection virale a été analysée avec le logiciel Statistica. La distribution spatiale des lianes infectées a été étudiée par la méthode d'analyse des classes de distance en deux dimensions (2Dclass). Résultats et discussion. Les résultats montrent que l'expression des symptômes n'est pas systématiquement associée à la présence de virus et, inversement, l'absence de symptôme ne signifie pas toujours qu'il y a absence de virus dans la plante. Les lianes sont majoritairement infectées par le CymV, virus qui se propage selon le rang de vanillier au gré des opérations culturales. Les potyvirus ont pu être transmis par des insectes vecteurs et également par contact, mais, dans ce dernier cas, moins efficacement que le CymV. Conclusion. Les résultats de cette étude sont exploités pour le développement de mesures de contrôle des épidémies incluant la production de matériel végétal sain. Les études en cours concernent la caractérisation des potyvirus et potexvirus de façon à optimiser des outils de diagnostic sérologique et moléculaire qui puissent être validés dans le cadre d'un programme de certification de boutures de vanilliers indemnes de virus.

Réunion / Vanilla fragrans / enquête pathologique / culture sous abri / potexvirus / potyvirus / symptôme / transmission des maladies / épidémiologie 


\section{Introduction}

Production of vanilla (Vanilla fragrans) in Reunion Island decreased from 80 t of green vanilla in 1992 to around $13 \mathrm{t}$ in 1995. This drop was mainly due to a rapid decline in black vanilla prices on the market from US\$ $70 \times \mathrm{kg}^{-1}$ to less than US\$ $50 \times \mathrm{kg}^{-1}$ in 1990 [1]. In view of this problem, a major project of intensified production was initiated in 1994. It consisted of growing vanilla vines $1 \mathrm{~m}$ apart in 10 to 15 rows of 27 to 37 vines, in a metal frame structure covered with a shade net (figure 1). However, viral diseases, recorded for the first time in 1995 in Reunion Island, were more severe under shade houses than in traditional rain forests and resulted in a quick decline of vanilla vines [1]. Thus, shade house cultivation practices increased vanilla yields to meet local needs but production might be improved, both in quantity and quality, if viral diseases could be managed.

In Reunion Island, both the cymbidium mosaic potexvirus (CymV) and potyviruses can seriously affect vanilla growth [2]. Elisa tests were conducted to determine if vines were infected with CymV [3], vanilla necrosis potyvirus (VNV) [4], vanilla mosaic potyvirus (VaMV) $[5,6]$ or with other potyviruses that may induce mild or no symptoms [7]. In contrast to the Pacific Islands where it does not induce severe disease symptoms [8], in Reunion Island CymV is commonly associated with necrosis of the vanilla stem and disorders of plant growth. Symptoms induced by potyviruses in Reunion Island, however, are not as severe as those associated with vanilla necrosis in the Pacific where infected plants usually die within 12 months. Moreover, potyviruses occurring in Reunion Island did not react strongly to antisera of either VNV [7] or VaMV [9] but reacted strongly to Agdia potyvirus group antiserum [2]. Temporal and spatial dynamics of $\mathrm{CymV}$ and potyviruses under shade houses are largely unknown and still confusing. During cultivation, the two groups of viruses can be mechanically transmitted from plant to plant on cutting tools and workers' hands. Potyviruses presumably can also be transmitted by aphids although very few aphids were observed on vanilla either in Reunion Island [2] or in the Pacific Islands, Tonga [7], and Moorea, Raiatea and Tahiti [5]. In this context, we surveyed five shade houses to gain a better understanding of viral distribution for recommending management strategies to control virus diseases in vanilla shade houses.
Shade house for intensified vanilla production in Reunion Island.

\section{Materials and methods}

\subsection{Disease surveys}

In July and November 1998 and in April 1999, extensive indexing for viruses was performed on plants in four shade houses named Cadet, Dijoux, Poulbassia and Leger. These shade houses were chosen based on results of a survey conducted in November 1997 [10]: one shade house was relatively disease free (Cadet), a second with plants infected only with potyviruses (Poulbassia), a third with plants infected only with CymV (Dijoux), and plants in a fourth were infected with both virus groups (Leger) (table I). A fifth shade house (Choute), used as a control and surveyed only in November 1998 and April 1999, was included after replanting with plants indexed by Elisa and determined to be virus free. Five leaf 
samples were collected from every plant in each shade house (350 to 400 vines per shade house). These samples were collected randomly on each vine regardless of whether symptoms were observed.

Symptoms were recorded on all plants, and five categories of symptoms were recognized (figure 2): none, chlorotic spots, chlorotic streaks, necrotic lesions, and mosaic with leaf distortion.

\subsection{Serological tests}

For potyviruses, leaf samples were assayed serologically using a broad spectrum

\section{Table I.}

Percentage of diseased vanilla plants detected with Elisa tests in four shade houses located in Reunion Islands, in November 1997.

$\begin{array}{lccc}\begin{array}{l}\text { Shade house } \\ \text { name }\end{array} & \begin{array}{c}\text { Number } \\ \text { of sampled plants }\end{array} & \begin{array}{c}\text { Plants } \\ \text { with CymV (\%) }\end{array} & \begin{array}{c}\text { Plants } \\ \text { with Potyviruses (\%) }\end{array} \\ \text { Cadet } & 343 & 0.00 & 0.3 \\ \text { Dijoux } & 431 & 25.80 & 0.5 \\ \text { Poulbassia } & 319 & 0.60 & 14.4 \\ \text { Leger } & 432 & 63.00 & 3.7\end{array}$

antiserum. These viruses were detected in an indirect plate-trapped antigen Elisa with monoclonal antiserum PTY-1 against the

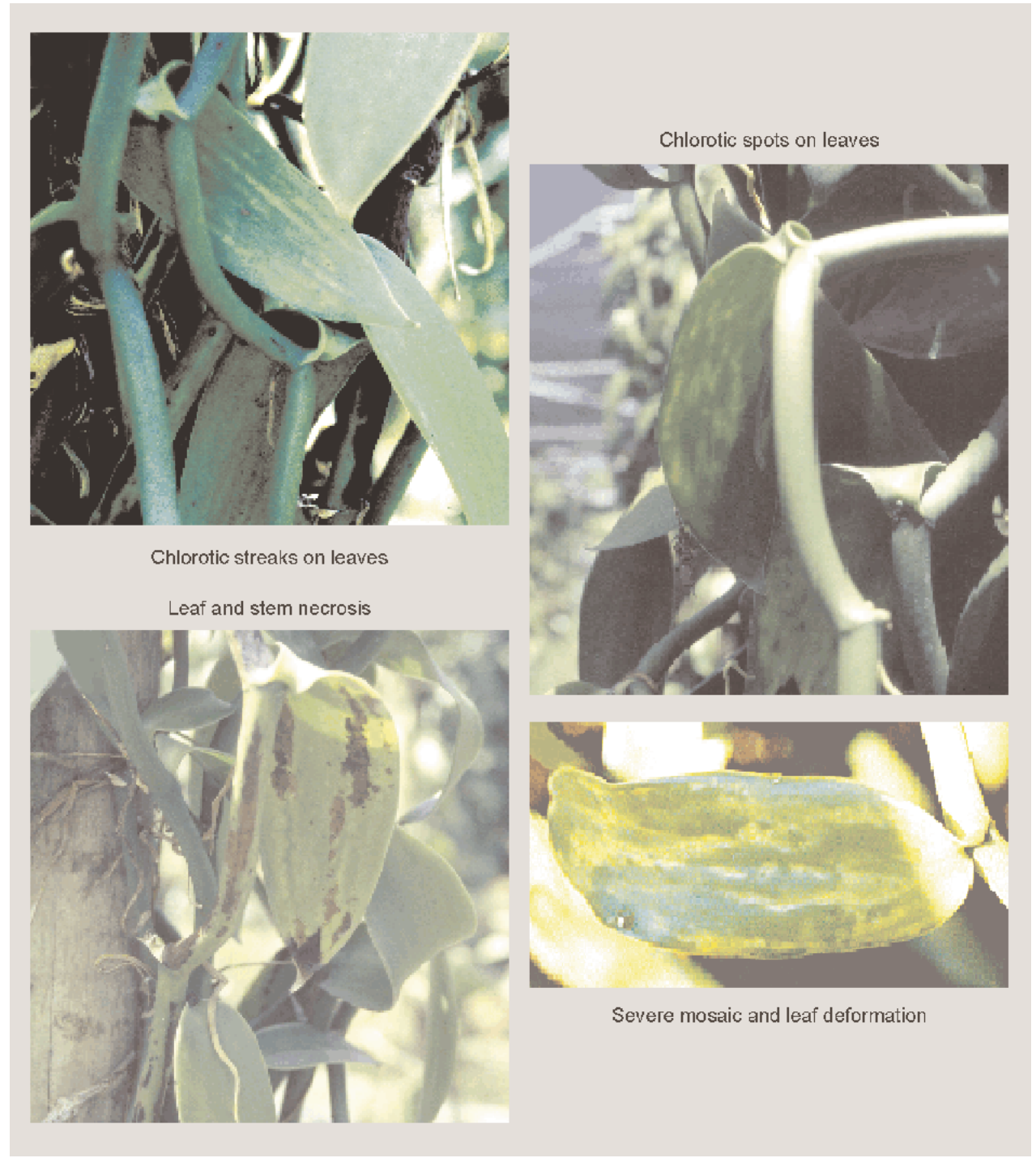

Figure 2.

Symptoms of viral diseases on vanilla vines (Vanilla fragrans). 
potyvirus group (Agdia, Elkhart, Indiana, USA). The PTY-1 monoclonal recognizes an epitope hidden within the capsid subunit which is conserved on many aphid-transmissible potyviruses [11]. Leaf samples were ground $(1: 10, \mathrm{w} / \mathrm{v})$ in sodium carbonate buffer $0.1 \mathrm{M}(\mathrm{pH}$ 9.6) and incubated in microtiter plates (Nunc Immuno-plate, Strasbourg, France) overnight at $4{ }^{\circ} \mathrm{C}$. Plates were then incubated for $2 \mathrm{~h}$ at $37^{\circ} \mathrm{C}$, first with monoclonal antiserum, then with phosphatase-conjugated anti-mouse immunoglobulin G (Sigma Immunochemicals, St Louis, Missouri, USA), both diluted in phosphate-buffered saline $0.1 \mathrm{M}$ ( $\mathrm{pH}$ 7.4) containing $0.5 \%$ Tween 20 and $0.5 \%$ bovine serum albumine. The final incubation with p-nitrophenyl phosphate substrate $\left(1 \mathrm{mg} \times \mathrm{mL}^{-1}\right)$ was in the dark at the room temperature until color development was obvious in the positive controls (usually $2 \mathrm{~h}$ ). The $\mathrm{OD}_{405 \mathrm{~nm}}$ was measured using an Elisa reader.

For CymV infection, leaf samples were tested by direct double antibody sandwich Elisa using specific CymV antisera kits (Agdia, Elkhart, Indiana, USA). In the first step, polyclonal antibodies diluted in sodium carbonate buffer were absorbed directly onto microtiter plates for $2 \mathrm{~h}$ at $37^{\circ} \mathrm{C}$. Then, leaf extracts $(1: 10, \mathrm{w} / \mathrm{v})$ in phosphatebuffered saline $0.1 \mathrm{M}(\mathrm{pH} 7.4)$ were added and incubated overnight at $4{ }^{\circ} \mathrm{C}$. The third step was to add to microtiter plates phosphatase-conjugated monoclonal antiserum for $2 \mathrm{~h}$ at $37^{\circ} \mathrm{C}$. $\mathrm{OD}_{405 \mathrm{~nm}}$ readings were performed $2 \mathrm{~h}$ after adding the substrate.

Tests were duplicated, and eight healthy controls were included per microplate. If the $\mathrm{OD}_{405 \mathrm{~nm}}$ distribution of the different healthy samples is considered to be normal and if we select the coefficient in a t distribution table (Student Fisher) by which the standard deviation (s) has to be multiplied to give a value which has a 0.005 probability to be exceeded, then the healthy limit on a given microplate is: $\mathrm{x}+3.5 \mathrm{~s}$ when referring to eight healthy values ( $\mathrm{x}$ being the average $\mathrm{OD}_{405 \mathrm{~nm}}$ value) [12].

\subsection{Statistical analysis}

Correlations between symptoms and viral diagnosis were established by means of multiple regressions using the Statistica (Statsoft, Maisons-Alfort, France) software (version 5.5, 1999). The spatial distribution of infected plants was analyzed with twodimensional distance class analysis software (2DClass) [13]. Simulations were conducted under the following conditions:

- percentage of infected plants $\geq 10 \%$ and $<90 \%$,

- percentage of missing values $<20 \%$,

- number of simulations performed: 400.

\section{Results}

\subsection{Symptom analysis}

Symptoms varied greatly between the three sampling dates. The frequency of plants exhibiting symptoms was higher during winter (July 1998) than during the following summer (November 1998) (table II). In April 1999, it was equal to or higher than the percentage of plants with symptoms in November 1998. In November 1998 and April 1999, the proportion of infected vines without symptoms exceeded the proportion of infected vines with symptoms in the Cadet, Dijoux and Poulbassia shade houses (table II). For the three sampling dates, the proportion of diseased vines without symptoms ranged between $16 \%$ and $19 \%$ in the Leger shade house.

Results of multiple regression analysis between the number of samples exhibiting symptoms and the number of diseased samples diagnosed after serological tests showed that occurrence of symptoms on vanilla leaves did not correlate to the number of plants testing positive for potyviruses (figure 3). However, infection by CymV could be related to symptom expression in the Leger and Dijoux shade houses in July 1998 and in November 1998 / April 1999, respectively (figure 4).

\subsection{Infection level}

All plantings were infected in April 1999 (figure 5) including plants in the Choute shade house that were planted with healthy 
Table II.

Percentage of vanilla plants exhibiting disease symptoms in four shade houses located in Reunion Island, according to three surveys.

\begin{tabular}{|c|c|c|c|c|c|c|c|c|c|}
\hline \multirow{3}{*}{$\begin{array}{l}\text { Shade house } \\
\text { Name }\end{array}$} & \multicolumn{3}{|c|}{ July 1998} & \multicolumn{3}{|c|}{ November 1998} & \multicolumn{3}{|c|}{ April 1999} \\
\hline & \multicolumn{2}{|c|}{ Vines with symptoms } & \multirow{2}{*}{$\begin{array}{l}\text { Vines without } \\
\text { symptoms } \\
\text { (Elisa tests) }\end{array}$} & \multicolumn{2}{|c|}{ Vines with symptoms } & \multirow{2}{*}{$\begin{array}{l}\text { Vines without } \\
\text { symptoms } \\
\text { (Elisa tests) }\end{array}$} & \multicolumn{2}{|c|}{ Vines with symptoms } & \multirow{2}{*}{$\begin{array}{c}\text { Vines without } \\
\text { symptoms } \\
\text { (Elisa tests) }\end{array}$} \\
\hline & Observation & Elisa tests & & Observation & Elisa tests & & Observation & Elisa tests & \\
\hline Cadet & 73.9 & 20.3 & 5.2 & 41.7 & 9.9 & 13.8 & 41.7 & 9.0 & 11.1 \\
\hline Dijoux & 90.0 & 44.1 & 3.5 & 38.0 & 22.7 & 36.9 & 43.0 & 36.5 & 40.5 \\
\hline Poulbassia & 75.3 & 8.3 & 0.0 & 49.4 & 1.3 & 3.1 & 59.8 & 6.8 & 7.5 \\
\hline Leger & 80.0 & 76.2 & 16.2 & 72.4 & 60.2 & 16.6 & 80.3 & 70.6 & 18.7 \\
\hline
\end{tabular}

cuttings in January 1998. The latter were infected by both CymV and potyviruses; the percentage of diseased plants in April 1999 reached $11.6 \%$ and $2.8 \%$, respectively.

In the Dijoux shade house, the progression of plants infected with CymV increased from one sampling date to another: $26 \%$ to $27 \%$ of plants were infected in November 1997 and in July 1998, which increased to over $50 \%$ by November 1998 and to $77 \%$ of sampled plants by April 1999. Plants infected with CymV were also numerous in the Leger shade house with $60 \%$ to $90 \%$ of the plants infected regardless of the date of survey. Detection levels during the winter (July and April) were higher than those recorded during the summer (November).

In the Cadet and Poulbassia shade houses, which had very few diseased vines in November 1997, plants infected with CymV were detected in November 1998 (7.8\% and $3.8 \%$, respectively). These infection levels did not increase in April 1999.

Unlike the CymV infection, the potyvirus infection did not increase consistently over time. Between November 1997 and July 1998, potyviruses infected more than 25\% of plants in the Cadet shade house but viruses did not spread any further and were detected in about 15\% of plants in November 1998 and April 1999. Likewise, the percentage of plants testing positive for potyviruses in the Leger shade house between November 1997 and July 1998

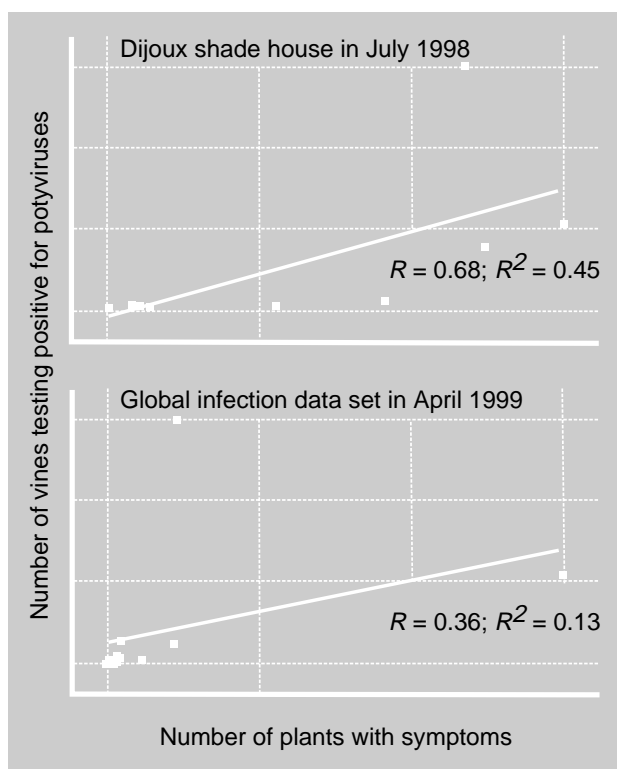

Figure 3.

Relationship between the number of vanilla vines with necrotic, chlorotic and/or mosaic symptoms and the number of vines infected with potyviruses (Elisa tests) in the Dijoux shade house in July 1998 or for global infection data set in April 1999 (Reunion Island).
(+11.2\%) subsequently decreased to roughly $7 \%$ of sampled plants in November 1998 and April 1999. These variations of virus detection levels were more pronounced in the Dijoux shade house so that the infection peak recorded in July 1998 (16\%) was not observed later on, and this area appeared nearly potyvirus-free in November 1998 and April 1999. The percentage of testing positive vines in the Poulbassia shade house also fluctuated in time since it regularly declined over a year of production, being nearly null in November 1998, then increasing again in April 1999 to reach 
Figure 4.

Relationship between the number of vanilla vines with necrotic, chlorotic and/or mosaic symptoms and the number of vines infected with the cymbidium mosaic potexvirus (CymV detected by Elisa tests) in various shade houses at different dates (Reunion Island).

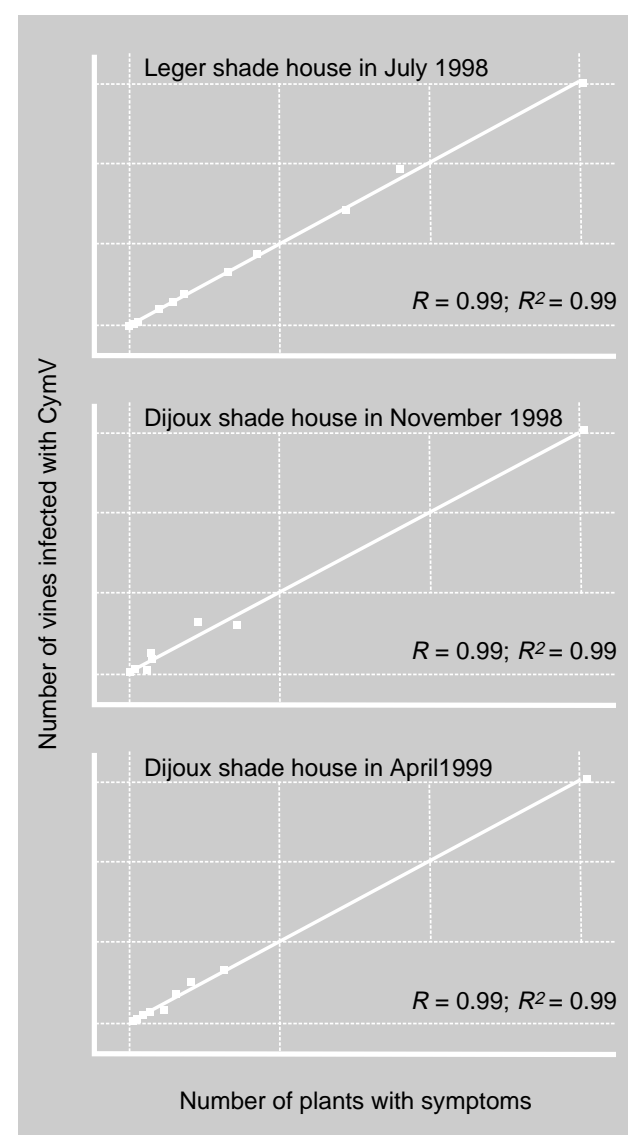

the level of infection recorded in November 1997.

\subsection{Spatial dynamic}

\subsubsection{CymV}

In the Dijoux shade house, the 2DClass matrices (figure 6, A-D; I-L) revealed a nonrandom distribution of vines infected with CymV regardless of the date of survey. In November 1997, infected plants were aggregated on one side of the shade house. In July 1998, plants infected with potexviruses remained confined to the right side of the shade house but aggregated in two foci where disease progressed gradually along the row. In November 1998, spread of CymV was so significant that previously observed foci coalesced and a new focus appeared on the left side of the shade house. In April 1999, epidemics still progressed along the rows and the area with distance classes with standardized count frequencies (SCF) lower than expected tended to be reduced showing the generalized pattern of diseased vines.

In the Leger shade house (figure 6, E-G; $\mathrm{M}-\mathrm{O}$ ), plants infected with CymV were already numerous in November 1997. Distance classes with SCF lower than expected $(0-19,7-14)$ showed that they were mainly located in the right part of the shade house. In November 1998 and, in April 1999, the number of vines infected with CymV exceeded $80 \%$, and in July 1998, it was more than $90 \%$ (data set not analyzed). This infection level resulted in a uniform spatial disease pattern not clearly demonstrated by the 2DClass method.

Initial infection of the Choute shade house (figure 6, H; P) with CymV had a nonrandom pattern and 2DClass analysis showed that diseased vines were localized in the row. The 2DClass method also allowed distinguishing of both large [distance classes with SCF significantly higher than expected (18-27, 8-11)] and small foci [distance classes with SCF significantly higher than expected $(4,2) ;(15,7) ;(24,0)]$.

\subsubsection{Potyviruses}

In July and November 1998 and in April 1999, 2DClass analysis (figure 7, A-C; F-H) carried out in the Cadet shade house revealed a number of SCF significantly higher than expected under the assumption of a random distribution pattern of infected plants. Distance classes $(1,0)$ and $(1,1)$ in July 1998 and $(1,0),(1,1)$ and $(0,1)$ in November 1998 were associated with SCF higher than expected showing the occurrence of small sized disease foci scattered throughout the shade house. The decrease of disease level in November 1998 resulted in a lower proportion of vines contaminated on the left part of the shade house and a spreading of infection foci on the right part. Although many plants that were infected in November 1998 appeared healthy in April 1999, the 2DClass analysis indicated two infection areas clearly separated one from another. The "exclusion" region in the central part of the matrix was represented by distance classes with 
significantly lower SCF values. Thus, foci described by a series of distance classes with SCF significantly higher $(0-27,0)$; $(0-27,9)$ and $(0-16,10)$ were confined to the right and left parts of the shade house and, in contrast to previous patterns, potyviruses tended to progress within the rows of vanilla plants.

In the Dijoux shade house, 2DClass matrices revealed a nonrandom distribution of plants infected with potyviruses (figure 7, D; I). In July 1998, infected plants appeared primarily on the left side of the shade house and were grouped in a large focus. During later surveys, potyviruses did not spread and rates of testing positive vines for potyviruses were too low for the 2DClass analysis.

Introduction of potyviruses to the Leger shade house in July 1998 resulted in the occurrence of small isolated foci randomly distributed on the grid illustrated by the lack of distance classes with SCF lower than expected on the 2DClass matrice (figure 7, E, J). As in the Dijoux shade house, no spreading of potyviruses was detected after this date of the survey.

For all data sets analyzed, there was no edge effect since distance classes with SCF significantly higher than expected were not noted in the $0-27$ or 28,12 or 13 or 14 regions nor in the 27 or $28,0-12$ or 13 or 14 regions.

\section{Discussion}

In vanilla shade houses, there are two phases of symptom expression:

- severe symptoms during the winter period (May-September) when many cultural practices (looping, pollination...) are carried out on vanilla vines in their slow vegetative development stage,

- a phase of recovery during the summer (October-April) when vanilla vines are growing rapidly, expressing little or no viral symptoms. These results agree with previous observations [1]. Symptoms on vanilla leaves did not correlate well with the plant infection. Neither CymV nor potyviruses

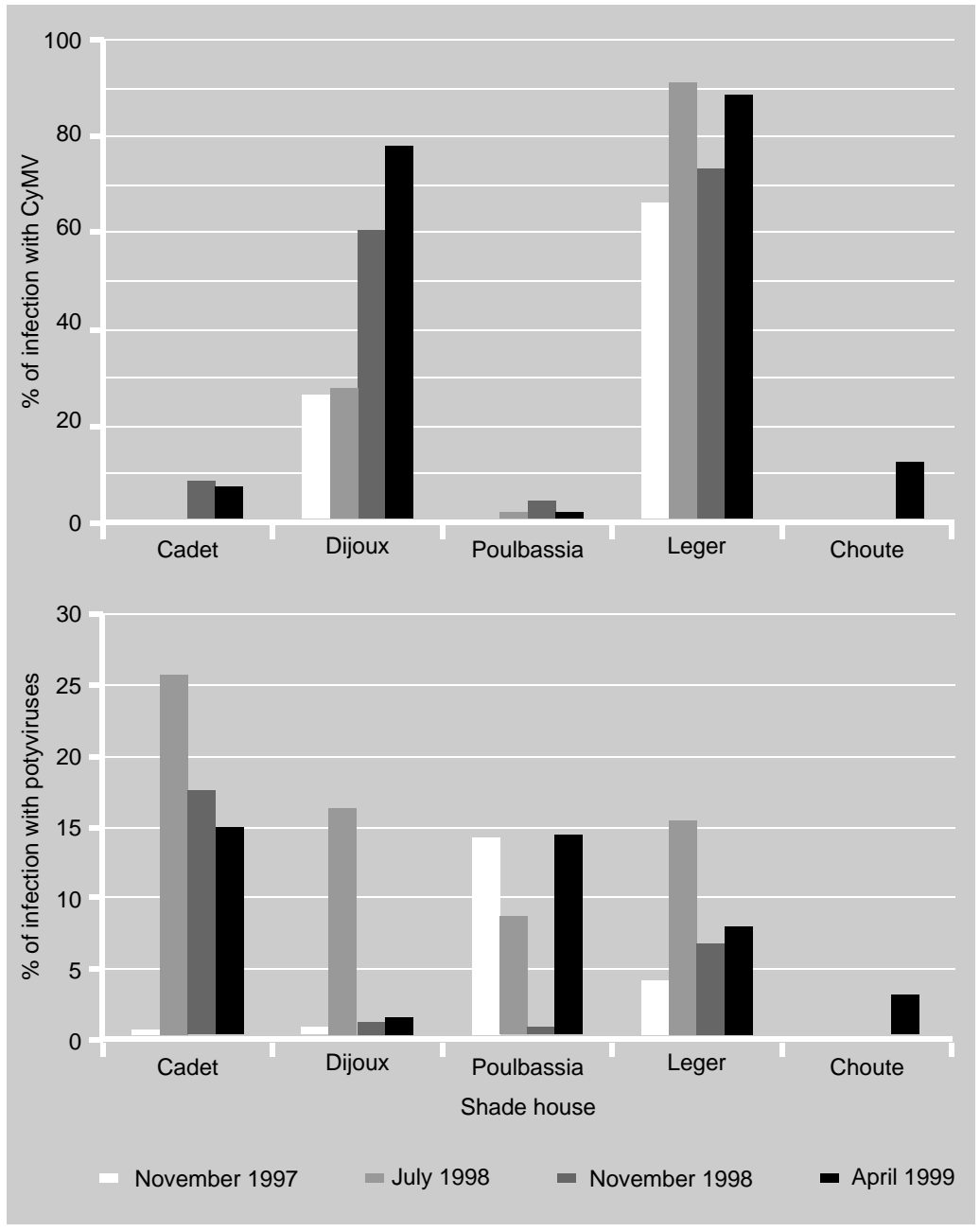

can be reliably detected in vanilla solely on the basis of symptoms. For example, in Reunion Island, the observation of necrotic lesions, previously described $[5,14]$ do not correlate with the occurrence of potyviruses in vanilla plants. Moreover, one cannot assume that apparently healthy plants are virus free, but it is nonetheless important to destroy all apparently diseased plants to reduce viral sources.

The study of temporal and spatial epidemic of viruses that affect vanilla in shade houses was our primary objective. Results show that the distribution in time and space of CymV and potyviruses is distinct.

During one 8-month period when no new cuttings were brought in, no new CymV infection occurred in the Cadet and
Figure 5.

Percentage of vanilla plants infected with the cymbidium mosaic potexvirus (CymV) or potyviruses in various shade houses at different dates (Reunion Island). 


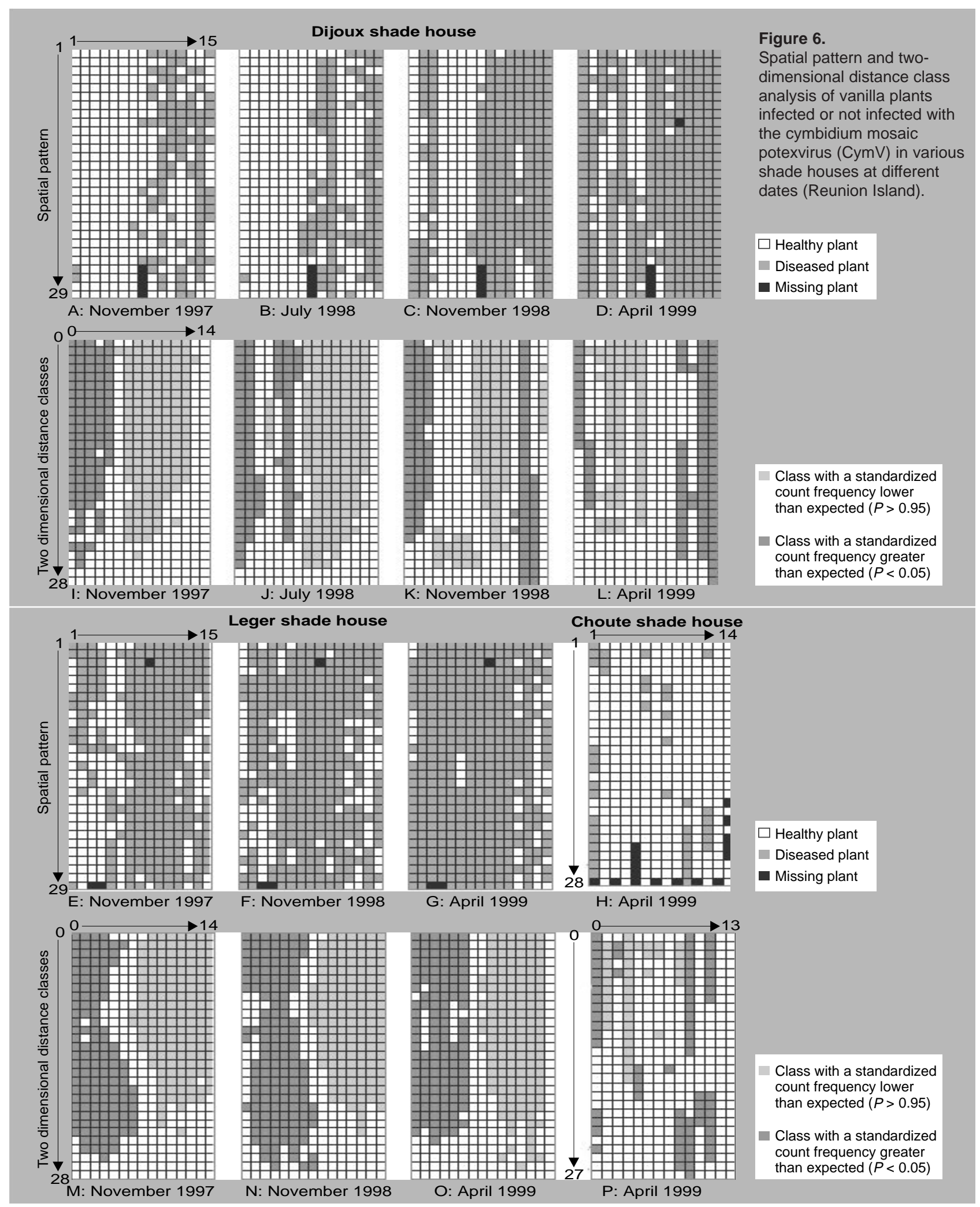




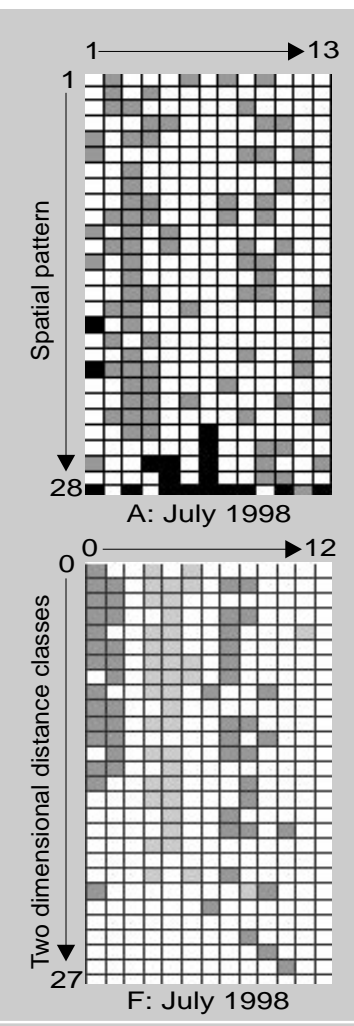

Cadet shade house

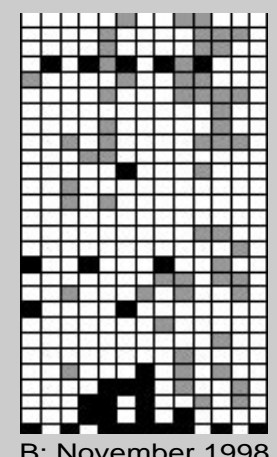

B: November 1998

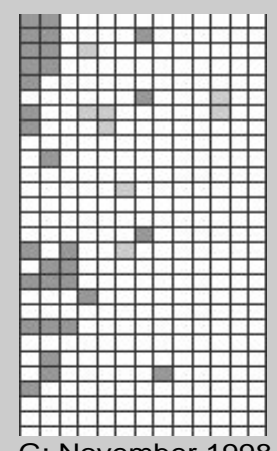

G: November 1998

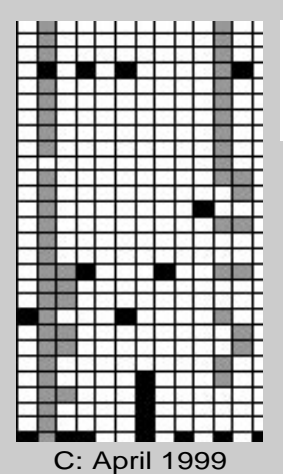

$\square$ Healthy plant

Diseased plant

- Missing plant

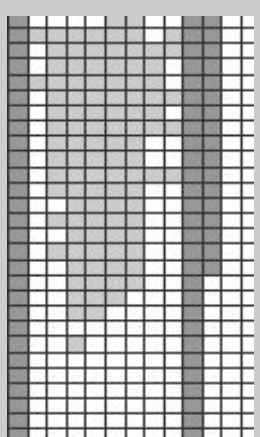

H: April 1999

Leger shade house

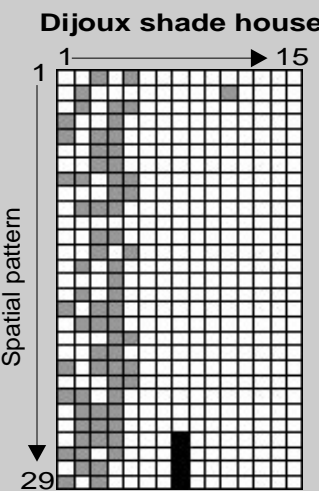

D: July 1998

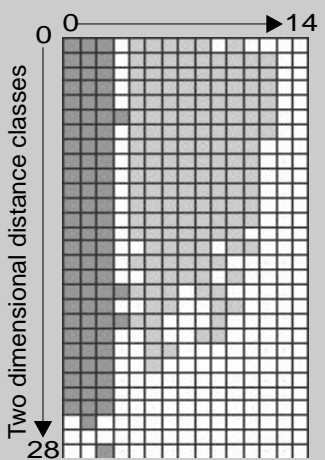

I: July 1998

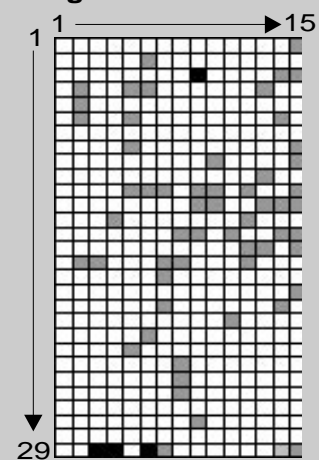

$\square$ Healthy plant

Diseased plant

- Missing plant

E: July 1998

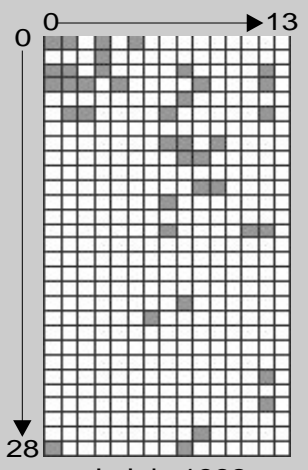

J: July 1998
Figure 7.

Spatial pattern

and two-dimensional distance

class analysis of vanilla plants infected or not infected with

potyviruses in various shade

houses at different dates

(Reunion Island). 
Poulbassia shade houses. But in another location during roughly the same period, CymV spread rapidly in large clusters primarily in the row. These results support the assumption that vanilla potexvirus is introduced into shade houses via infected cuttings collected in fields especially, and spread with time is essentially due to cultural practices, mainly artificial pollination (flowers are hand-pollinated using a sharpened stick).

Although knowing the viral risk related to planting vines collected in vanilla fields, farmers nonetheless use this plant material to replace decaying vines. These replants could explain the occurrence of new $\mathrm{CymV}$ infections in the shade houses.

The decreasing rate of plants testing positive for potyviruses has a seasonal feature in that it is especially obvious in the summer period (November) during quick vegetative growth of vanilla when no or few symptoms occurred. The number of diseased vines removed and replaced with healthy ones is too low to explain the fluctuations of vines testing positive for potyviruses between November 1997 and April 1999 (no replants the Leger in shade house; 3, 5 and 10 replants in the Poulbassia, Dijoux and Cadet shade houses, respectively). Variations in vines testing positive for potyviruses could depend on a recovery of the plant resulting in less virus in the plant related to quick growth of the plant in summer. They could also be due to an erratic viral distribution in plants inducing bias in the sampling method based on symptom expression.

However, occurrence of potyviruses in the Cadet and Leger shade houses in small distinctive foci could be explained by viral infection by means of insect vectors. These infection foci did not enlarge but remained scattered except in one instance when disease progressed along the rows of vanilla plants.

These results allow us to issue warning schedules to prevent disease outbreaks and spread by:

- removing and destroying vanilla plants with virus symptoms, and replacing them with cuttings from a virus-free nursery,
- washing hands, and cutting and pollination tools between each vanilla plant,

- removing weed seeds under and near shade houses to limit virus and aphids sources,

- avoiding growing other plant species in the shade house such as leguminous, palm tree and decorative plants that could be virus-infected or habor aphid vectors.

The best long term method of controlling vanilla viruses is to prevent virus entering the shade house by using only virusfree planting material. For that purpose, a nursery of virus-tested vanilla plants for use in new plantings has been established since 1999 in Reunion especially to combat cymbidium mosaic potexvirus.

Characterization of potyvirus isolates should be investigated through reliable serological, molecular and biological methods. A better understanding of potyviruses will help to understand:

- seasonal features of viral infection,

- viral kinetics in vanilla vines,

- transmission of potyviruses by aphids: within shade houses, three main aphid species were collected and kindly identified by F. Leclant (Inra, Montpellier, France), namely Aphis gossypii, Aphis spiraecola and Cerataphis orchidearum; these species were also collected on Vanilla tahitensis and Vanilla support trees (Gliricidia sepium) in French Polynesia [5] and could be involved in the transmission of vanilla potyviruses [5, 7],

- the role of plant sources in viral epidemic.

\section{Acknowledgment}

We wish to acknowledge SCA Provanille and the Conseil général of Reunion Island for their financial support.

\section{References}

[1] Côme B., Gambin O., Synthèse des premiers travaux sur les viroses des cultures de vanille sous ombrière, Provanille-FDGDEC, St-Pierre, île de la Réunion, 1997, 10 p. 
[2] Pearson M.N., Assessment of vanilla virus problem in île de la Réunion, Rapport de mission, Auckland Univ., New Zealand, 1997 $17 \mathrm{p}$.

[3] Wisler G.C., Zettler F.W., Purcifull D.E., Two viruses of Vanilla in Society Islands, Abstr., Phytopathology 76 (1986) 1091.

[4] Pearson M.N., Pone S.P., Viruses of vanilla in the Kingdom of Tonga, Aust. Plant Pathol. 17 (3) (1988) 59-60.

[5] Wisler G.C., Zettler F.W., Mu L., Virus infections of vanilla and other orchids in French Polynesia, Plant Dis. 71 (1987) 1125-1129.

[6] Zettler F.W., Ko N.J., Wisler G.C., Elliot M., Wong S.M., Viruses of orchids and their control, Plant Dis. 74 (1990) 621-625.

[7] Pearson M.N., Brunt A.A., Pone S.P., Some hosts and properties of a potyvirus infecting Vanilla fragrans (Orchidaceae) in the Kingdom of Tonga, J. Phytopathol. 128 (1990) 46-54.

[8] Pearson M.N., Jackson G.V.H., Pone S.P., Howitt R.L.J., Vanilla viruses in the South Pacific, Plant Pathol. 42 (1) (1993) 127-131.

[9] Wang Y.Y., Pearson M.N., Some characteristics of potyvirus isolates from Vanilla tahiten sis in French Polynesia and the Cook Islands, J. Phytopathol. 135 (1992) 71-76.
[10] Bénézet H., Picard E., Côme C., Grisoni G., Leclercq-Le Quillec F., Gambin O., Jeuffrault E., Les virus du vanillier à la Réunion : un frein au développement de la culture sous ombrière, Phytoma 526 (2000) 40-42.

[11] Jordan R., Hammond J., Comparison and differentiation of potyvirus group-common epitopes using monoclonal antibodies, J. Gen. Virol. 72 (1991) 25-36.

[12] Maury Y., Bossennec J.M., Boudazin G., Hampton R.O., Pietersen G., Maguire J.D., Factors influencing Elisa evaluation of transmission of pea seed-borne mosaic virus in infected pea seed: seed group size and seed decortication, Agronomie 7 (4) (1987) 225-230.

[13] Ferrandino F.J., Two dimensional distance class analysis of disease-Incidence data: problems and possible solutions, Phytopathology 86 (7) (1996) 685-691.

[14] Liefting L., Pearson M.N., Pone S.P., The isolation and evaluation of two naturally occurring mild strains of vanilla necrosis potyvirus for control by cross-protection, J. Phytopathol. 136 (1992) 9-15.

\section{Diseminación en sombría del cymbidium mosaic potexvirus y de potyvirus que afectan a las lianas de vainillas cultivadas en la isla de la Reunión.}

Resumen - Introducción. Desde 1994, la seca de ramillas de la vainilla, cultivada en sistema intensivo bajo sombría en la isla de la Reunión, se debe principalmente al "cymbidium mosaic virus" (CymV) y a los potyvirus. Para limitar los daños y controlar mejor la epidemia viral, hemos estudiado la relación entre la presencia de síntomas y el diagnóstico viral así como la dinámica temporal y espacial de los virus en sombría. Estos estudios se han utilizado para aportar recomendaciones profilácticas adecuadas y crear un vivero de estaquillas de vainilla para suministrar a los plantadores un material vegetal sin virus. Material y métodos. La observación de los síntomas y el serodiagnóstico se realizaron a partir de hojas de vainilla (Vanilla fragrans) con ocasión de diferentes inspecciones bajo sombrías. La relación entre la expresión de los síntomas y los datos de infección viral se analizó con el software Statistica. Se estudió la distribución espacial de las lianas infectadas mediante el método de análisis de clases de distancia en dos dimensiones (2Dclass). Resultados y discusión. Los resultados muestran que la expresión de los síntomas no está asociada sistemáticamente a la presencia del virus y que, al contrario, la ausencia de síntomas no significa siempre que el virus esté ausente de la planta. Las lianas están mayoritariamente infectadas por el CymV, virus que se propaga por 
las hileras de vainilla durante las operaciones de cultivo. Los potyvirus se han podido transmitir por insectos vectores y, también, por contacto pero, en este último caso, de forma menos eficaz que el CymV. Conclusión. Se aprovechan los resultados de este estudio para el desarrollo de medidas de control de epidemias que incluyan la producción de material vegetal sano. Los estudios que se realizan actualmente conciernen la caracterización de potyvirus y potexvirus para optimizar unos instrumentos de diagnóstico serológico y molecular que puedan ser validados en el marco de un programa de certificación de estaquillas de vainilla libres de virus.

Reunión / Vanilla fragrans / encuestas sanitarias / cultivo protegido / umbría / virosis / potexvirus / potyvirus / síntomas / transmisión de enfermedades / epidemiologia 